\title{
ASSESSMENT OF SEEDLING ABUNDANCE, SURVIVAL AND GROWTH OF TWO DIPTEROCARP SPECIES IN PEAT SWAMP FORESTS OF BRUNEI DARUSSALAM
}

\author{
HAZIMAH HAJI MOHD DIN, NOR BASIRAH BAKIRI, RAHAYU SUKMARIA SUKRI \\ and FAIZAH METALI* \\ Environmental and Life Sciences Programme, Faculty of Science, Universiti Brunei Darussalam, Gadong BE1410, \\ Brunei Darussalam
}

Received 31 January 2017 / Accepted 21 March 2018

\begin{abstract}
Dryobalanops rappa Becc. and Shorea albida Sym. are Bornean endemics of high conservation value and increasingly threatened by anthropogenic disturbances. In-situ study of seedling abundance and growth performance of these Dipterocarp species was conducted in two selected peat swamp forests of Brunei Darussalam, following a mast fruiting event in March-May 2014. Within six 6 x $6 \mathrm{~m}$ plots at each forest site, D. rappa seedlings at the Anduki peat swamp forest and $S$. albida seedlings at the Badas peat swamp forest were measured for abundance at the initial census in September 2014, as well as survival and relative growth rates (RGR) after a period of 5 months, with the final census in February 2015. We found significantly higher seedling abundance for D. rappa (1885 \pm 208$)$ than S. albida (160 \pm 71$)$. Significantly higher percentage survival was recorded for $D$. rappa seedlings $(90.8 \pm 2.2 \%)$ in comparison to $S$. albida seedlings $(81.7 \pm 2.2 \%)$. S. albida seedlings $\left(0.24 \pm 0.02 \mathrm{~mm} \mathrm{~mm}^{-1} \mathrm{month}^{-1}\right)$ showed significantly greater RGR in stem diameter than $D$. rappa seedlings $\left(0.18 \pm 0.02 \mathrm{~mm} \mathrm{~mm}^{-1} \mathrm{month}^{-1}\right)$, however, there were no significant differences in the RGRs based on seedling height, leaf number and biomass between D. rappa and S. albida seedlings. In terms of seedling abundance and percentage survival, D. rappa seedlings appeared to be more successful in regeneration and may potentially be used for rehabilitation of degraded tropical peat swamps and other forest types. Our results suggested that greater conservation efforts of peat swamps must be made to protect the Bornean endemic plant species, in particular S. albida.
\end{abstract}

Keywords: Borneo, Dipterocarpaceae, Dryobalanops rappa, relative growth rates, Shorea albida

\section{INTRODUCTION}

Peat swamp forest is a unique ecosystem that represents the second major forest type in Brunei Darussalam, accounting for $15.6 \%$ (or $90,884 \mathrm{ha}$ ) of Brunei's forest (Wong et al. 2015; Forestry Department 2016). It is mainly located in the Belait district, interconnecting with the peat swamps of the Baram basin in Sarawak. Bornean peat swamp forests are ombrogenous and have six 'phasic communities', each consisting of distinct plant communities (Anderson 1963). Over the years, there has been a significant reduction in peat swamps in Brunei Darussalam mainly due to infrastructure development and forest fires $(\mathrm{Pg}$ Harun 2015; Wong 2016). Peat swamps house

\footnotetext{
* Corresponding author: faizah.metali@ubd.edu.bn
}

unique flora, some of which are endemic and increasingly threatened in their natural ranges due to anthropogenic disturbances such as legal or illegal logging, forest fires and land-use changes (Yule 2010; Posa et al. 2011). Most tree families in lowland dipterocarps are found in peat swamps, but many peat swamp species are restricted and physiologically adapted to this extreme forest environment ( $\mathrm{Ng} \&$ Ibrahim 2001).

In Brunei Darussalam, extensive stands of Dryobalanops rappa Becc. or 'Kapur paya' exist on shallow peat overlying sand in Lumut and Anduki, while pure stands of Shorea albida Sym. occur in the 'padang alan' and 'alan bunga' peat swamp forests of Badas, both in the Belait District (Anderson 1964; Ashton et al. 2003; Wong et al. 2015). The Anduki peat swamp forests experienced massive forest fires during the 
1997-1998 El Niño drought (Wooster et al. 2012), resulting in fragmented stands of intact $D$. rappa existing within an otherwise developed area. Low regeneration rates have been observed in natural D. rappa populations (Wong \& Kamariah 1999), and this species is increasingly threatened from illegal logging (Phillips 1998). The Badas peat swamps consist of gregarious stands of $S$. albida that are decreasing in population density and have been showing few signs of natural regeneration for the past 30 years (Kobayashi 1998). The IUCN Red List classifies $S$. albida as endangered due to rapid population loss within its natural forest ranges, coupled with a regeneration status that is reported to be virtually non-existent (Ashton 1998). Furthermore, S. albida is endemic to north and west Borneo (Ashton 1998) and so the remaining stands in the Badas peat swamps in Brunei are likely to be one of the few remaining intact stands of $S$. albida in Borneo and globally (Forestry Department 2014).

Both $D$. rappa and $S$. albida are important timber tree species that rely on irregular mass flowering and mast fruiting episodes as a means of their natural regeneration (Appanah \& Turnbull 1998). Although several studies have been conducted on the survival and growth of Dipterocarpaceae seedlings in Bornean forests (Turner 1990; Delissio et al. 2002; Nakagawa et al. 2005; Shimamura et al. 2006; Takeuchi \& Nakashizuka 2007; Daisuke et al. 2013), only a few have focussed specifically on peat swamp species (Ibrahim 1996; Gavin \& Peart 1997; Saito et al. 2005; Jans et al. 2012), and no study has been conducted on $S$. albida seedlings to date.

Following a small mass flowering and a mast fruiting event in the Badas and Anduki peat swamps in March-May 2014, the abundance, survival and growth of $D$. rappa and S. albida seedlings at the understorey of these two peat swamp forests were assessed in Brunei Darussalam. Our study provides preliminary findings on two native Dipterocarp species that can potentially be utilised in efforts to naturally regenerate and rehabilitate disturbed peat swamp forests.

\section{MATERIALS AND METHODS}

The study was conducted in the Anduki and Badas peat swamps located in the Belait district, Brunei Darussalam, north-west Borneo, at distances of $c a .14 \mathrm{~km}$ from each other by road. A dominant dipterocarp species (Dipterocarpaceae) in each peat swamp site was selected. The Anduki peat swamp $\left(4^{\circ} 37^{\prime} 39.00^{\prime \prime} \mathrm{N}, 114^{\circ} 22^{\prime} 1.14^{\prime \prime} \mathrm{E}\right)$ is located in the coastal areas of Belait district within the Anduki Forest Reserve and is dominated by Dryobalanops rappa Becc. The Badas peat swamp $\left(4^{\circ} 34^{\prime} 9.12^{\prime \prime} \mathrm{N}, 114^{\circ} 24^{\prime} 40.08^{\prime \prime} \mathrm{E}\right)$ is located further inland, south of Seria and is mainly populated by Shorea albida Sym. A total of six plots $(6 \mathrm{~m} \times 6 \mathrm{~m}$ or $36 \mathrm{~m}^{2}$ each) plots were set up: three plots of Shorea albida at Badas and three plots of Dryobalanops rappa at Anduki. Plots were located $c a .50 \mathrm{~m}$ away from each other and each plot was set up with a mother tree of the respective species located at the centre of the plot. Abundance of D. rappa seedlings in Anduki and S. albida seedlings in Badas were quantified per plot at the initial census in September 2014, ca. 3-5 months after the mass flowering and mast fruiting events. Within each plot, 40 seedlings of either D. rappa (at Anduki) or $S$. albida (at Badas) were randomly chosen and tagged in September 2014. The seedling censuses were conducted twice, in September 2014 and after 5 months, in February 2015. The tagged seedlings were measured for percentage survival, stem height (measured from the point of measurement painted white on soil surface to the top leaf bud), stem diameter and number of leaves (counted fully expanded leaves, excluding heavily eaten leaves i.e. approximately $70 \%$ of lamina eaten and dead leaves) at both censuses.

A total of 10 seedlings of each species were randomly chosen from outside each of the three study plots per census and harvested to provide estimates of initial and final dry biomass. At both harvests, seedlings were washed with distilled water, oven-dried at $60^{\circ} \mathrm{C}$ for $48 \mathrm{~h}$ and weighed. The relative growth rate (RGR) based on stem height (RGRH), stem diameter (RGRD), number of leaves (RGRL) and biomass (RGRB) per 
seedling over the five-month census period were calculated following Hunt (1982): RGR $=\left(\log _{\mathrm{e}} W_{2}\right.$ $\left.-\log _{\mathrm{e}} W_{1}\right) /\left(t_{2}-t_{1}\right)$, where $W_{2}$ and $W_{1}$ are stem height, stem diameter, total number of leaves or biomass and $t_{2}-t_{1}$ is 5 months. To compute RGRB, seedlings were paired by ranked values of seedling biomass at the initial and final harvests.

Between-species differences seedling abundance, percentage seedling survival and RGR values were determined using t-tests in $\mathrm{R} 2.15 .2$ ( $\mathrm{R}$ Core Team 2014). All data were first explored to confirm the normality of residuals and homogeneity of variances, and where necessary, data was $\log _{10}$-transformed, with the exception of percentage survival, which was arcsinetransformed.

\section{RESULTS AND DISCUSSION}

Using the initial census survey, D. rappa seedlings at the Anduki peat swamp forest showed significantly higher mean abundance per $36 \mathrm{~m}^{2}$ plots compared to $S$. albida seedlings at the Badas peat swamp (D. rappa: $1885 \pm 208$ vs. S. albida: 160 $\pm 71, p<0.01)$. This is a probable reflection of the higher density of adult $D$. rappa trees in Anduki, compared to the more sparsely populated adult $S$. albida trees in Badas (pers. obs.). Additionally, the higher $D$. rappa seedling abundance may be due to higher abundance of flowering mother trees, as almost all mature D. rappa trees flowered at Anduki whilst not all mature $S$. albida trees flowered at Badas during the same mass flowering event in 2014 (pers. obs.). Other studies have similarly documented a positive relationship between the number of mother trees and seedling density, with the highest seedling densities found in areas with high adult abundance (Itoh et al. 1997; Webb \& Peart 1999; Backlund 2013).

Mean percentage survival of tagged $D$. rappa seedlings over the period of 5 months was significantly greater than $S$. albida seedlings ( 90.8 $\pm 2.2 \%$ vs. $81.7 \pm 2.2 \%, p<0.05)$. All relative growth rates (RGRs) data of both species showed similar growth rates (Fig. 1) that there were no significant differences in all relative growth rates (RGR) except for RGR in stem diameter (RGRD), in which $D$. rappa seedlings had significantly lower RGRD than those of $S$. albida seedlings $(0.18 \pm$ 0.02 vs. $0.24 \pm 0.02 \mathrm{~mm} \mathrm{~mm}^{-1}$ month $^{-1} ; \mathrm{p}<0.01$; Fig. 1B). Other studies in Brunei Darussalam have recorded higher survival and RGR for D. rappa seedlings planted in lowland mixed dipterocarp forest (Sukri 2010) and degraded heath forest (W. H. Tuah, unpubl. data). Natural disturbance within the understorey may influence the survival of tree seedlings (Appanah \& Turnbull 1998) and can be an explanation for the low percentage survival of S. albida. Yamada (1997) reported that Badas peat swamp has higher incidences of fallen trees and presence of buttress roots on its forest floor compared to Anduki peat swamp. During the rainy season between December 2014 January 2015 in Badas, S. albida seedlings may not survive when hit by fallen trees and branches, thus decreasing its survival percentage. Through the mast fruiting period, the $S$. albida seeds may fall on the false forest floor in Badas, which is formed from litter accumulation on buttress roots. This may lead to $S$. albida seedlings mortality as the false floor may fall to the peat when disturbed.

Seedling predation and microenvironment also influence seedling survival, and it has been recorded elsewhere in Borneo that late fruiting of Shorea species increased the possibility of seed losses to predation (Curran \& Webb 2000). Anduki peat swamp has different physiological environment compared to Badas peat swamp forest in terms of its natural disturbance. Fragmentation of the Anduki forest due to rapid forest fires may cause its forest floor to develop shallow litter and peat overlying sandy soil (Yamada 1997). The Anduki Forest Reserve is dependent on waterlogged conditions to maintain the peat bog (Yussof 2015) and D. rappa seedlings are well-adapted to waterlogged peat (Yamada \& Suzuki 2004). Survival and growth of $S$. albida seedlings have been found to be negatively affected by low light intensity (Kobayashi 1998), water shortage during dry spells (Kobayashi 1998) and excessive water during rainy period (Dixon et al. 2013), which may be factors that explain their low survival rates in Badas.

D. rappa is a light-demanding species (Ashton et al. 2003), while S. albida seedlings have been recorded as shade-intolerant (Kobayashi 1998; pers. obs.). Regardless of the light environment, light-demanders tend to possess larger specific leaf area and higher photosynthetic capacity, which result in greater carbon gain, and potentially higher survival, compared to shadetolerant species (Ghazoul \& Sheil 2010). Light has 


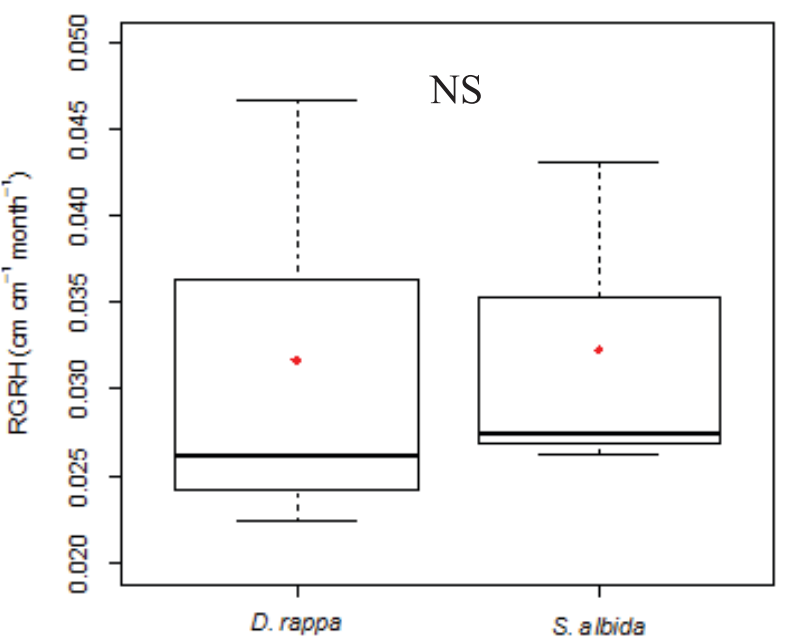

(A) RGR based on stem height

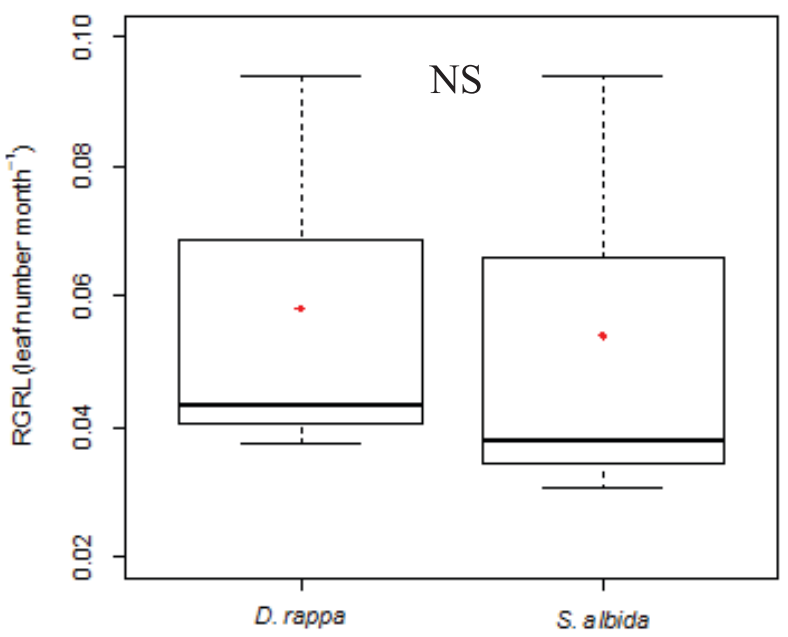

(C) RGR based on leaf number

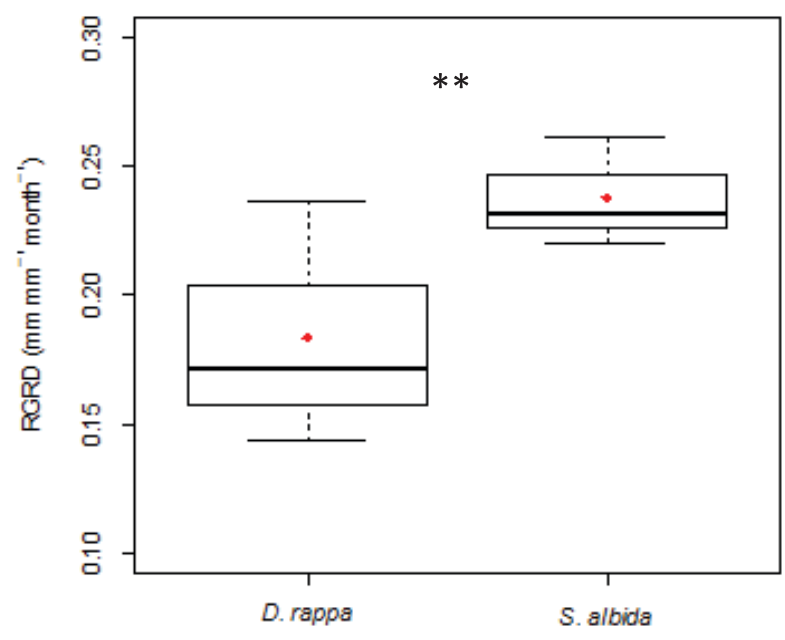

(B) RGR based on stem diameter

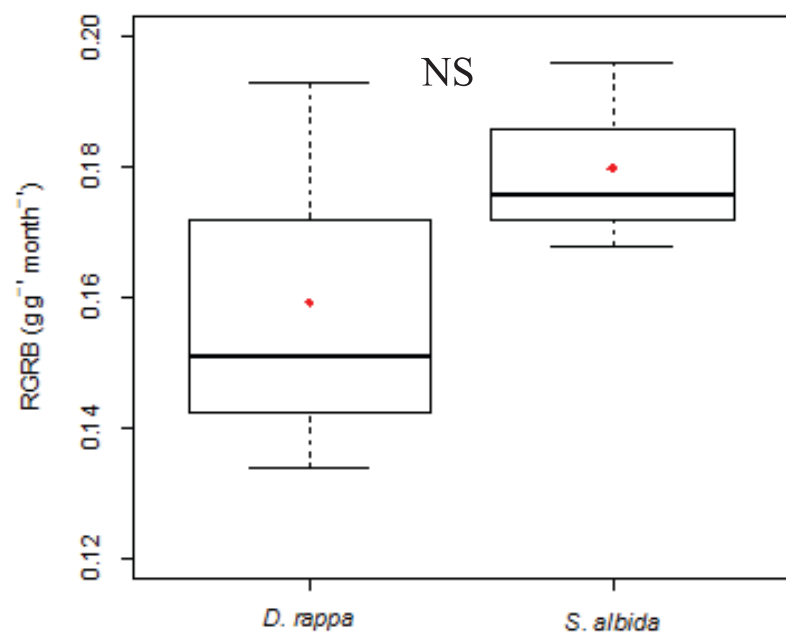

(D) RGR based on biomass

Figure 1 Differences in relative growth rates (RGR) for Dryobalanops rappa seedlings in Anduki and Shorea albida seedlings in Badas: (A) RGRH (stem height; $\mathrm{cm} \mathrm{cm}^{-1}$ month $^{-1}$ ), (B) RGRD (stem diameter; $\mathrm{mm} \mathrm{mm}^{-1} \mathrm{month}^{-1}$ ), (C) RGRL (number of leaves; leaf number month $^{-1}$ ) and (D) RGRB (biomass; $\mathrm{g} \mathrm{g}^{-1} \mathrm{month}^{-1}$ ). RGR data were determined for the 40 tagged $D$. rappa and $S$. albida seedlings, except for RGRB which was determined for the 10 seedlings harvested outside each plot at each census. The asterisk sign within each RGR denotes significant differences of means between species (marked with red dots) using t-tests $(*, p<0.05 ; * *, p<0.01 ; * * *, p<0.001$ ). NS $=$ Nonsignificant.

been recognised to significantly influence survival and growth of Dipterocarp seedlings (Scholes et al. 1996; Whitmore \& Brown 1996). For example, D. rappa and S. albida saplings were planted in the open in ongoing reforestation trial plots of degraded waterlogged heath forests (Kerapah forests) in Brunei Darussalam, and have performed successfully in terms of its survival and growth rates over a period of more than a year (W. H. Tuah, unpubl. data).
It was found that $S$. albida seedlings had significantly higher RGRD compared to D. rappa seedlings. This suggests that in the shaded understorey of peat swamp forests, S. albida seedlings allocated more resources to stem diameter growth than height growth. Tropical tree species that preferentially invest resources into stem diameter growth and wood density typically exhibit traits that defend against herbivory and pathogens, as well as for the 
development of their root system (Kitajima 1994), all of which decrease investment into height growth. The Badas peat swamp forest has a flat, densely crowded canopy (Yamada 1997), which restricts light entry to the understorey and may further inhibit height growth of S. albida seedlings. These shade-intolerant $S$. albida seedlings (Kobayashi 1998) require ample light to grow in height. Higher growth rates of $S$. albida in the open areas than in the closed canopy forest was recorded in the ongoing rehabilitation trial plots in the Kerapah forests of Brunei Darussalam (W. H. Tuah, unpubl. data).

Both the Dryobalanops rappa peat swamp forest in Anduki as well as the Shorea albida peat swamp forest in Badas have been identified as critical habitats that are of high conservation value (Forestry Department 2014). Peat swamps are highly vulnerable to fires, particularly during the dry season and when the water table have been lowered (Yule 2010). Changes in drainage and hydrological conditions significantly increase repeated fire events (Posa et al. 2011). Repeated fires in Anduki and Badas, especially during drier periods and drought events, coupled with slow seedling growth rates, will undoubtedly result in further losses of both D. rappa and S. albida populations. In the case of S. albida, this loss will be further exacerbated by the low number of survived seedlings and mother trees flowering at the same time (pers. obs.).

\section{CONCLUSION}

This study recorded significant findings on Dryobalanops rappa seedlings in Anduki and Shorea albida seedlings in Badas. D. rappa seedlings were more abundant than $S$. albida seedlings, and also showed higher percentage seedling survival. $S$. albida seedlings, however, appeared to invest more in stem diameter growth, as their relative growth rate in terms of stem diameter was significantly higher compared to D. rappa seedlings. We suggest that $D$. rappa seedlings may be suitable as a species that can be used to rehabilitate degraded peat swamp forests, but detailed, longer term studies are needed to further support this conclusion. Finally, given that peat swamps forests are fast disappearing due to natural and anthropogenic disturbances, their protection and conservation efforts should be prioritised to protect the
Bornean endemic plant species, in particular $S$. albida.

\section{ACKNOWLEDGEMENTS}

The authors thank the Forestry Department, Ministry of Primary Resources and Tourism (MPRT), Brunei Darussalam for granting permission to conduct research in the Anduki and Badas peat swamps (No. [84]/JPH/UND/17 PT.1), and the Brunei National Herbarium, MPRT for providing information on the mass flowering and mast fruiting episodes. We thank the technical staff of Environmental and Life Sciences, Universiti Brunei Darussalam (UBD) for their assistance with field equipment. Funding for this project was provided by UBD for NBB.

\section{REFERENCES}

Anderson JAR. 1963. The flora of the peat swamp forests of Sarawak and Brunei, including a catalogue of all recorded species of flowering plants, ferns and fern allies. Singapore (SG): Gard. Bull. Singapore. p. 131228.

Anderson JAR.1964. The structure and development of peat swamps of Sarawak and Brunei. J Trop Geo 18:7-16.

Appanah S, Turnbull JW. 1998. A Review of Dipterocarps: Taxanomy, ecology and silviculture. Bogor (ID): CIFOR.

Ashton P [Internet]. 1998. Shorea albida, the IUCN red list of threatened species 1998. e.T33099A9751699; [cited 2016 Dec 8]. Available from: http://dx.doi.org/10.2305/IUCN.UK.1998.RLTS. T33099A9751699.en

Ashton PS, Kamariah AS, Said IM. 2003. Field guide to the forest trees of Brunei Darussalam and the Northwest Borneo hotspot. Bandar Seri Begawan $(\mathrm{BN})$ : University of Brunei Darussalam in association with Brunei Forestry Department, Brunei Shell Petroleum and Sultan Haji Hassanal Bolkiah Foundation.

Backlund S. 2013. The effects of mother trees and site conditions on the distribution of natural regeneration establishment in a Bornean rainforest disturbed by logging and fire [Thesis]. Retrieved from Swedish University of Agricultural Sciences.

Curran LM, Webb CO. 2000. Experimental tests of the spatiotemporal scale of seed predation in mast-fruiting Dipterocarpaceae. Ecol Monogr 70(1):129-48. 
Daisuke H, Tanaka K, Jawa KJ, Ikuo N, Katsutoshi S. 2013. Rehabilitation of degraded tropical rainforest using dipterocarp trees in Sarawak, Malaysia. Int J Forestry Res: 683017. doi: 10.1155/2013/683017

Delissio LJ, Primack RB, Hall P, Lee HS. 2002. A decade of canopy-tree seedling survival and growth in two Bornean rain forests: Persistence and recovery from suppression. J Trop Ecol 18(5):645-58.

Dixon C, Fyson GF, Pasiecznik N, Praciak A, Rushforth K, Sassen M, ... van Heist M. 2013. The CABI encyclopedia of forest trees. Oxfordshire (UK): CABI Publishing.

Forestry Department. 2014. The $5^{\text {th }}$ national report to the convention on biological diversity. Bandar Seri Begawan (BN): The Forestry Department, Ministry of Industry and Primary Resources.

Forestry Department [Internet]. 2016. Forest Types: Peat Swamp. Bandar Seri Begawan, BN: Forestry Department; [cited 2016 Dec 9]. Available from: http://www.forestry.gov.bn/

Gavin DG, Peart DR. 1997. Spatial structure and regeneration of Tetramerista glabra in peat swamp rain forest in Indonesian Borneo. Plant Ecol 131(2):22331.

Ghazoul J, Sheil D. 2010. Tropical rain forest ecology, diversity and conservation. Oxford (UK): Oxford University Press.

Hunt R. 1982. Plant growth curves: The functional approach to plant growth analysis. London (UK): Edward Arnold Ltd.

Ibrahim S. 1996. Gonystylus bancanus: Some observations on its flowering, fruiting, seed predation and germination. J Trop Forest Sci 8(3):424-6.

Itoh A, Yakamura T, Ogino K, Lee HS, Ashton PS. 1997. Spatial distribution patterns of two predominant emergent trees in a tropical rainforest in Sarawak, Malaysia. Plant Ecol 132(2):121-36.

Jans WWP, Dibor L, Verwer C, Kruijt B, Tan S, van der Meer PJ. 2012. Effects of light soil flooding on the growth and photosynthesis of ramin (Gonostylus bancanus) seedlings in Malaysia. J Trop For Sci 24(1):54-63.

Kitajima K. 1994. Relative importance of photosynthetic traits and allocation patterns as correlates of seedling shade tolerance of 13 tropical trees. Oecologia 98(34):419-28.

Kobayashi S. 1998. Forest structure and regeneration process of peat swamp Alan forests (Shorea albida) in Brunei Darussalam. In: Suhartoyo H, Fatawi M, editors. Proceedings of the Second International Symposium on Asian Tropical Forest Management. p. 166-87.

Nakagawa M, Takeuchi Y, Kenta T, Nakashizuka T. 2005. Predispersal seed predation by insects vs. vertebrates in six Dipterocarp species in Sarawak, Malaysia 1. Biotropica 37(3):389-96.
Ng TP, Ibrahim S. 2001. Common trees in peat swamp forests of Peninsular Malaysia. Kepong (MY): Forest Research Institute.

Pg Harun AMK [Internet]. 2015. Construction projects damage Belait peatlands. Bandar Seri Begawan, BN: The Brunei Times; [cited 2015 Oct 28]. Available from: http://bt.com.bn/

Phillips VD. 1998. Peat swamp ecology and sustainable development in Borneo. Biodivers Conserv 7(5):651-71.

Posa MRC, Wijedasa LS, Corlett RT. 2011. Biodiversity and conservation of tropical peat swamp forests. BioScience 61(1):49-57.

R Core Team [Internet]. 2014. R: A language and environment for statistical computing. Vienna, AT: R Foundation for Statistical Computing; [cited 2016 Dec 1]. Available from: https://www.Rproject.org/

Saito H, Shibuya M, Tuah SJ, Turjaman M, Takahashi K, Jamal Y, ... Limin SH. 2005. Initial screening of fastgrowing tree species being tolerant of dry tropical peatlands in Central Kalimantan, Indonesia. J Forestry Res 2(2):1-10.

Scholes JD, Press MC, Zipperlen SW. 1996. Differences in light energy utilisation and dissipation between dipterocarp rain forest tree seedlings. Oecologia 109(1):41-8.

Shimamura T, Momose K, Kobayashi S. 2006. A comparison of sites suitable for the seedling establishment of two co-occurring species, Swintonia glauca and Stemonurus scorpioides, in a tropical peat swamp forest. Ecol Res 21(5):759-67.

Sukri RSH. 2010. Differentiation of dipterocarp floristic composition and species distributions in Brunei Darussalam [Dissertation]. Retrieved from University of Aberdeen.

Takeuchi Y, Nakashizuka T. 2007. Effect of distance and density on seed/seedling fate of two dipterocarp species. Forest Ecol Manag 247(1):167-74.

Turner IM. 1990. The seedling survivorship and growth of three Shorea species in a Malaysian tropical rain forest. J Trop Ecol 6(4):469-78.

Webb CO, Peart DR. 1999. Seedling density dependence promotes coexistence of Bornean rain forest trees. Ecology 80(6):2006-17.

Whitmore TC, Brown ND. 1996. Dipterocarp seedling growth in rain forest canopy gaps during six and a half years. Philos T R Soc 351(1344):1195-203.

Wong A [Internet]. 2016. Forest fires serious threat to large tree native to Borneo. Bandar Seri Begawan, BN: The Brunei Times; [cited 2016 Apr 11]. Available from: http://bt.com.bn/

Wong KM, Kamariah AS. 1999. Forests and trees of Brunei Darussalam. Bandar Seri Begawan (BN): Universiti 
Brunei Darussalam, Forestry Dept., Ministry of Industry and Primary Resources and Brunei Shell Petroleum Company Sendirian Berhad.

Wong KM, Ahmad JA, Low YW, Kalat MAA. 2015. Rainforest plants and flowers of Brunei Darussalam. Bandar Seri Begawan (BN): Forestry Department, Ministry of Industry and Primary Resources.

Wooster MJ, Perry GLW, Zoumas A. 2012. Fire, drought and El Niño relationships on Borneo (Southeast Asia) in the pre-MODIS era (1980-2000). Biogeosciences $9(1): 317-40$.

Yamada I. 1997. Tropical rainforests of Southeast Asia. Honolulu (US): University of Hawaii Press.
Yamada T, Suzuki E. 2004. Ecological role of vegetative sprouting in the regeneration of Dryobalanops rappa, an emergent species in a Bornean tropical wetland forest. J Trop Ecol 20(4):377-84.

Yule CM. 2010. Loss of biodiversity and ecosystem functioning in Indo-Malayan peat swamp forests. Biodivers Conserv 19(2):393-409.

Yussof M [Internet]. 2015. HoB initiative to battle global warming. Borneo Bulletin; [cited 2015 Oct 3]. Available from: http://borneobulletin.com.bn 